\title{
Micro-Propagation of Aloe indica L. Through Shoot Tip Culture
}

\author{
Gokul Chandra Biswas ${ }^{1}$, Md. Abunasar Miah ${ }^{1}$, M. M. Hasan Sohel ${ }^{2}$, \\ A. K. M. Shahadat Hossain ${ }^{3}$, Shahriar Kabir Shakil ${ }^{1}$ and \\ Moniruzzaman Sohag Howlader ${ }^{1}$ \\ ${ }^{1}$ (Department of Genetic Engineering and Biotechnology, School of Life Science, Shahjalal University of \\ Science and Technology, Sylhet-3114, Bangladesh) \\ ${ }^{2}$ (Biotechnology Division, Bangladesh Institute of Nuclear Agriculture, Mymensingh-2202,Bangladesh) \\ ${ }^{3}$ (Bangladesh Jute Research Institute, Farm Division, Bangladesh)
}

\begin{abstract}
Shoot tip of Aloe indica L. variety was chosen as explants which disinfected with $2 \% \mathrm{NaOCl}$ and washing thoroughly with sterile water. The shoot tip explants were placed on MS medium supplemented with Benzyladenin, Kinetin with various concentrations were $0.5 \mathrm{mg} / \mathrm{L}, 1 \mathrm{mg} / \mathrm{L}, 1.5 \mathrm{mg} / \mathrm{L}$ and $2 \mathrm{mg} / \mathrm{L}$ and Benzyladenin along in combination with Napthaleneacetic acid the concentration were $0.5 \mathrm{mg} / \mathrm{L}+0.5 \mathrm{mg} / \mathrm{L}$, $1 \mathrm{mg} / \mathrm{L}+0.5 \mathrm{mg} / \mathrm{L}, 1.5 \mathrm{mg} / \mathrm{L}+0.5 \mathrm{mg} / \mathrm{L}$ and $2 \mathrm{mg} / \mathrm{L}+0.5 \mathrm{mg} / \mathrm{L}$. After 8 weeks, the best proliferation of average number of shoot per explants was 7.8 for the medium containing of $2 \mathrm{mg} / \mathrm{l}$ Benzyladenine with $0.5 \mathrm{mg} / \mathrm{l}$ Naphthaleneacetic acid and the lowest average number of shoot per explants was 0.9 for the medium containing of $0.5 \mathrm{mg} / \mathrm{L}$ Benzyladenine. For rooting, MS media supplemented with Napthaleneacetic acid, Indole-3-butyric acid acid and Indole-3-acetic acid with various concentration were $0.1 \mathrm{mg} / \mathrm{L}, 0.5 \mathrm{mg} / \mathrm{L}, 1 \mathrm{mg} / \mathrm{L}$ and $1.5 \mathrm{mg} / \mathrm{L}$ respectively were used. Highest average number of root per explants was 5.2 produced in $0.5 \mathrm{mg} / \mathrm{L}$ Napthaleneacetic acid concentration. On the other hand, the lowest average number of root per explants was zero with $0.1 \mathrm{mg} / \mathrm{L}$ Indole-3-acetic acid concentrations. Finally, the best shooting and rooting medium was identify MS medium in combination with $2 \mathrm{mg} / \mathrm{L}$ Benzyladenin with $0.5 \mathrm{mg} / \mathrm{L}$ Napthaleneacetic acid and $0.5 \mathrm{mg} / \mathrm{L}$ Napthaleneacetic acid respectively. Thus, this study could be ideal for rapid micropropagation of elite plants of Aloe indica L. By this protocol in future the cost of Aloe indica production will be decreased which will lead the decrease of aloe product prices.
\end{abstract}

Keywords: Aloe indica; charcoal; in vitro culture; micropropagation; MS medium; shoot tip.

\section{Introduction}

Aloe indica L. is the mostly used medicinal plant belongs to the family Liliaceae. The word Aloe indica appears to be derived from Arabic word "Alloeh", which means "a shining bitter substance." There are many romantic tales about Aloe, suggesting that Egyptian queens, Nerfertiti and Cleopatra, used it as part of their regular beauty regimen [1]. Supposedly Alexander the Great in 333 B.C occupied the island of Socotra in the Indian Ocean for its famed Aloe supplies, needed to treat his wounded soldiers [2].

Aloe is also common in both traditional Chinese and Ayurvedic medicine. The Chinese describe Aloe's skin and the inner lining of its leaves as a cold, bitter remedy which is downward draining and used to cure constipation due to accumulation of heat as the gel is considered cool and moist [3]. In Ayurvedic medicine, the traditional medicine of India, Aloe has multiple uses inclusive of laxative, antihelminthic, hemorrhoid remedy, and uterine stimulant. It is used topically, often in combination with licorice root, to treat eczema or psoriasis. In Arabian medicine, the fresh gel is used on the forehead as a headache remedy or rubbed on the body to cool it in case of fever, as well as being used for wound-healing, conjunctivitis, and as a disinfectant and laxative [1]. The aloe gel has been extensively used in gastrointestinal disorders, including peptic ulcer, and its clinical efficacy has been documented [4]. The first real investigation, which provided scientific enlightenment concerning Aloe's therapeutic efficacy started early in twentieth century. That was the age when the medicinal chemists traveled extensively and bought back plants, reputed for medical applications including cathartics, in order to isolate and characterize active substances using the chemistry of the day.

In recent times, Aloe vera gel has been used as an active ingredient in hundreds of skin lotions, sun blocks and cosmetics [5]. The gel's use in cosmetics has been increased by claims that it has anti-aging effects similar to vitamin A derivatives [5]. Recently, Aloe extracts have been used to treat canker sores stomach ulcers etc [4] and [6]. Aloe is also an ingredient in Compound Benzoin tincture [7]. The research studies conducted on Aloe vera plant have revealed that through strengthening the T-lymphocyte cells of the blood, it is able to heal the wounds and improve immunity [8]. Aloe vera gel bestowed with very powerful immune-modulatory effect can be used in AIDS, TB, and Cancer patients to overcome the symptoms and to prolong their life span.

For rapid multiplication of plants, tissue and organ culture technique is crucial tool now days. Although Aloe vera propagates vegetatively in its natural state, but propagation is too slow for commercial plant 
production [9]. To overcome slow propagation rate, micro propagation will be a very useful technique for mass multiplication of Aloe. The in vitro vegetative propagation has important benefits to produce stable lines in plants that have no named varieties e.g., Annona spp. [10] and Australian dioecious papaw genotypes [11] where traditional plant breeding has failed. It has also a great potential for the propagation of important crops like: Cassava spp., Phaseolus spp., Solanum spp., [12]. Worldwide there is much interest to promote the development of an in vitro technology that permits the propagation and breeding of commercial valuable woody, semi woody, ornamental, basic food, industrial and medicinal plants. Which species are in danger of extinction should receive a priority in terms of germplasm conservation [13].

\section{Materials And Methods}

Considering the medical importance and slower propagation rate, this micro propagation research work on Aloe indica L. was conducted in the BCSIR Laboratory, Rajshahi, Bangladesh. The detail of materials used and analytical methods employed during this study is given below:

\subsection{Plant materials}

Lateral shoots (suckers) of $A$. indica (one month old) collected from experimental Aloe indica $L$. garden of BCSIR Laboratory, Rajshahi used as the explants. Explants were prepared by removing roots and brown colored tissues and extending leaf portions to give an average size of $3-4 \mathrm{~cm}$. They were washed thoroughly with running tap water for about 10 minutes till all soil and other foreign materials washed off. Sets of twenty explants were then washed with tap water containing a few drops of Tween 20 and rinsed in $70 \%$ ethanol for 30 seconds followed by initial soaking in sodium hypochlorite containing approximately $4 \%$ available chlorine for 10 minutes and then in freshly prepared mercuric chloride solution $(0.1 \%)$ for 10 minutes. Finally they were washed 3-4 times with sterile distilled water before culturing

\subsection{Culture media} hormones.

The basal medium used for the culture is MS medium [14] with 3\% sucrose and $0.8 \%$ agar with growth

\subsection{Shooting and culture conditions}

The $\mathrm{pH}$ of the medium was adjusted to 5.7 and then cultures were incubated at $25 \pm 0^{\circ} \mathrm{C}$, under cool white fluorescent tubes with $16 \mathrm{~h}$ photoperiod.

\subsection{Shooting of Explants}

Explants devoid of contaminations were then inoculated on the MS basal medium supplemented with different concentrations of $\mathrm{BA}(0.5 \mathrm{mg} / \mathrm{L}), \mathrm{Kn}(1.0 \mathrm{mg} / \mathrm{L})$ and $\mathrm{BA}(1.5 \mathrm{mg} / \mathrm{L}))$ along in combination with NAA $(2.0 \mathrm{mg} / \mathrm{L})$. Shoots amplified from lateral shoot explants in shoot induction media were detached from explants and transferred on to a shoot elongation medium containing $1.0 \mathrm{gm} / \mathrm{L}$ activated charcoal.

\subsection{Rooting of Micro shoots}

After growing of shoot (Two months old), $4-5 \mathrm{~cm}$ tall shoots was inoculated into MS medium containing different concentrations of NAA, IBA and IAA individually. For NAA, IBA and IAA the concentration were $0.1 \mathrm{mg}, 0.5 \mathrm{mg} / \mathrm{L}, 1.0 \mathrm{mg} / \mathrm{L}$ and $1.5 \mathrm{mg} / \mathrm{L}$ for each.

\subsection{Hardening of plantlets}

About 5-6cm tall, well rooted plantlets were taken out from the culture vessels after one month from root induction media into plastic containers for acclimatization.

\subsection{Statistical Analysis}

The experimental design was factorial with R.B.D basis design, which was done with unequal repetition. All the experiments were carried into ten replicates with four treatments. Data were subjected to ANOVA (analysis of variance) and significant differences between treatments were determined by DMRT using the SPSS software package.

\subsubsection{Calculation of percent of shoots and roots induction from culture}

Number of shoots was recorded and the percentage of shoot regeneration was calculated as:

Per cent $(\%)$ of shoot induction $=\frac{\text { Number of explants induced shoot }}{\text { Number of explants incubated }} \times 100$ 
The percentage of root formation was calculated as:

Per cent $(\%)$ of root formation $=\frac{\text { Number of shootsinduced root }}{\text { Number of shootsincubated }} \times 100$

\subsubsection{Calculation of percent of plant establishment}

The percentage of established plants was calculated based on the number of plantlets placed in the pot and the number of plants finally established or survived by the following equation-

$$
\text { Per } \operatorname{cent}(\%) \text { plant establishment }=\frac{\text { Number of established plantlets }}{\text { Number of total plantlets placed in the plot }} \times 100
$$

\subsection{Induction, proliferation and multiplication}

\section{Results}

After inoculation of explants into MS Medium, it starts to show signs of proliferation after two weeks of culturing. New buds starts to appear from the axils of leaves of shoot explants and buds develop into shoots by 4 weeks of culture (Figure 1a). Microshoots were incubated on MS basal medium with different concentrations of BA, Kn and BA in combination with NAA for shoot proliferation (Table 3.1).

Table 3.1 Effect of different concentration of BA, Kn and BA with NAA on shoot proliferation (After 8 weeks of culture).

\begin{tabular}{|c|c|c|c|}
\hline $\begin{array}{c}\text { Name of the } \\
\text { Hormone }\end{array}$ & Hormone concentration(mg/L) & Percentage of shoot induction & $\begin{array}{l}\text { Number of shoot per explants } \\
(\text { Mean } \pm \text { SD) }\end{array}$ \\
\hline \multirow[t]{5}{*}{ Benzyaladenin } & 0.0 & 0 & $0^{-}$ \\
\hline & 0.5 & 60 & $0.90+0.87^{\mathrm{a \dagger}}$ \\
\hline & 1.0 & 80 & $1.90 \pm 1.37^{\mathrm{a}}$ \\
\hline & 1.5 & 90 & $2.70+1.25^{b}$ \\
\hline & 2.0 & 70 & $2+1.50^{\mathrm{b}}$ \\
\hline \multirow[t]{5}{*}{ Kinetin } & 0.0 & 0.0 & 0.0 \\
\hline & 0.5 & 60 & $1.60 \pm 1.5^{\mathrm{a}}$ \\
\hline & 1.0 & 70 & $2.30+1.34^{\mathrm{a}}$ \\
\hline & 1.5 & 80 & $2.70 \pm 1.49^{b}$ \\
\hline & 2.0 & 100 & $4.20 \pm \mathbf{0 . 6 3}^{\mathrm{b}}$ \\
\hline \multirow{5}{*}{$\begin{array}{l}\text { Kinetin }+ \\
\text { Benzyaladenin }\end{array}$} & 0.0 & 0.0 & 0 \\
\hline & $0.5+0.5$ & 70 & $5.4 \pm 4.05^{\mathrm{a}}$ \\
\hline & $1.0+0.5$ & 80 & $3.7 \pm 1.80^{\mathrm{a}}$ \\
\hline & $1.5+0.5$ & 90 & $6.6+2.54^{b}$ \\
\hline & $2.0+0.5$ & 100 & $7.8 \pm 0.78^{b}$ \\
\hline
\end{tabular}

Above the table, it was found that Kn gave better shoot proliferation than BA. When explants were treated with only BA, the best outcome of average number of shoots per explant was 2.70 for $1.5 \mathrm{mg} / \mathrm{L}$ hormone concentration; whereas $\mathrm{Kn}$ was 4.20 for $2 \mathrm{mg} / \mathrm{L}$ hormone concentration and BA in combination with NAA was 7.80 for $2 \mathrm{mg} / \mathrm{L}$ hormone concentration.

On the other hand, in case of BA $(1.5 \mathrm{mg} / \mathrm{L})$ highest percentage of shoot induction were identify as $90 \%, \mathrm{Kn}$ were $100 \%$ and BA $(2.0 \mathrm{mg} / \mathrm{L})$ in combination with NAA $(2.0 \mathrm{mg} / \mathrm{L}+0.5 \mathrm{mg} / \mathrm{L})$ were $100 \%$. Note that the least number of shoots per explant (nil) was shown in hormone-free medium.

Table 3.2 Statistical analysis of Aloe indica $L$. after 8 weeks of culture when MS medium containing different concentration of BA, NAA and BA with NAA.

\begin{tabular}{|c|c|c|c|c|c|}
\hline Source of variance & Sum of squares (SS) & Degree of Freedom (D.F.) & Mean squares (MS) & $F_{\mathrm{cal}}$ & $F_{0.5}$ \\
\hline Block (PGR's) & 3697.17 & 3 & 1848.58 & \multirow[b]{4}{*}{16.28} & \multirow[b]{4}{*}{4.78} \\
\hline Treatment & 877.67 & 2 & 292.56 & & \\
\hline Error & 107.83 & 6 & 17.97 & & \\
\hline Total & 4682.67 & 11 & & & \\
\hline
\end{tabular}

$\left[\right.$ Here, $\left.\mathrm{Fcal}_{>} \mathrm{F}_{0.5}.\right]$

So from the ANOVA Table we can conclude that on shoot proliferation BA, Kn and BA $\times$ NAA has significant effect. From the data of $F_{\text {cal value }}$ we find that the effect of $\mathrm{BA} \times \mathrm{NAA}$ is best and effect of $\mathrm{Kn}$ is better than $\mathrm{BA}$ (Table 3.2). 


\subsection{Inhibition of browning}

When adventitious roots were separated from the primary induction media and cultured individually, the roots severely browned and died. According to [15] reported that supplementation of PVP in the media inhibited browning in aloe tissue culture. However, we did not obtain any significant improvements with these additions. In our studies we used activated charcoal to control browning (Fig.1c and 1d).

\subsection{Induction and proliferation of adventitious roots}

NAA was the only phytohormone to induce adventitious roots from leaf explants after three weeks of culture (Figure 1b). No adventitious roots were initiated in auxin-free media. Old leaves and shoots greater than $10 \mathrm{~cm}$ in size did not induce adventitious roots under any conditions. Significant effects of NAA, IBA and IAA concentration were observed for adventitious root induction. For NAA supplement of lower concentrations, such as $0.1,0.5$ and $1.0 \mathrm{mg} / \mathrm{L}$ was good for adventitious root induction. Collectively, NAA $0.5 \mathrm{mg} / \mathrm{L}$ was the most effective for bringing about improvements in induction rate (90\%), number of adventitious roots per explants (5.1) and root length during six weeks of culture (Table 3.3)

Table 3.3 Effect of different concentration of NAA, IBA and IAA on root induction.

\begin{tabular}{|c|c|c|c|}
\hline Name of the hormone & Hormone concentration (mg/L) & \% explants producing root & $\begin{array}{l}\text { Number of root per explants } \\
\text { (Mean } \pm \text { SD) }\end{array}$ \\
\hline \multirow{3}{*}{ NAA } & 0.1 & 90 & $3.9 \pm 1.44^{\mathrm{a}}$ \\
\cline { 2 - 4 } & 0.5 & 100 & $5.2 \pm 1.61^{\mathrm{a}}$ \\
\cline { 2 - 4 } & 1.0 & 80 & $4 \pm 2.21^{\mathrm{b}}$ \\
\cline { 2 - 4 } & 1.5 & 70 & $3.7 \pm 2.71^{\mathrm{b}}$ \\
\hline \multirow{3}{*}{ IBA } & 0.1 & 50 & $2.20 \pm 2.34^{\mathrm{a}}$ \\
\cline { 2 - 4 } & 0.5 & 80 & $2.4 \pm 1.42^{\mathrm{a}}$ \\
\cline { 2 - 4 } & 1.0 & 90 & $4.20 \pm 2.61^{\mathrm{b}}$ \\
\cline { 2 - 4 } & 1.5 & 70 & $3.30 \pm 2.35^{\mathrm{b}}$ \\
\hline \multirow{3}{*}{ IAA } & 0.1 & 0.0 & 0.0 \\
\cline { 2 - 4 } & 0.5 & 20 & $1.1 \pm 2.33^{\mathrm{a}}$ \\
\cline { 2 - 4 } & 1.0 & 30 & $2.2 \pm 2.86^{\mathrm{b}}$ \\
\cline { 2 - 4 } & 1.5 & 40 & \\
\hline
\end{tabular}

[N.B: Values followed by same latter are not significantly different $(\mathrm{p}<0.05)$ using DMRT].

On the other hand, treatment of only IBA showed the best outcome of average number of shoots per explants was 3.19 for $1.0 \mathrm{mg} / \mathrm{L}$ hormone concentration and IAA were 2.22 for $1.5 \mathrm{mg} / \mathrm{L}$ hormone concentration. The least number of shoots per explant (nil) was shown in hormone concentration $0.1 \mathrm{mg} / \mathrm{L}$ (Table 3.3).

Table 3.4 Statistical analysis of Aloe indica $L$. after 8 weeks of culture when MS medium containing different concentration of NAA, IBA and IAA.

\begin{tabular}{|c|c|c|c|c|c|}
\hline Source of variance & Sum of squres (SS) & Degree of freedom (D.F.) & Mean square (MS) & $F_{\text {cal }}$ & $\mathbf{F}_{0.5}$ \\
\hline Block(PGR's) & 1893.17 & 2 & 946.58 & \multirow[b]{4}{*}{5.75} & \multirow[b]{4}{*}{4.46} \\
\hline Treatment & 240.92 & 3 & 80.31 & & \\
\hline Error & 83.83 & 6 & 13.97 & & \\
\hline Total & 2217.92 & 11 & & & \\
\hline
\end{tabular}

So from the ANOVA Table (Table 3.4) we can conclude that on root formation NAA, IBA and IAA has significant effect. From the data of $F_{\text {cal value }}$ we found that the effect of NAA is better than IBA and IAA is less effective. Finally we can conclude that for commercial micropropagation $2.0 \mathrm{mg} / \mathrm{L} \mathrm{BA}$ with NAA is best for shoot production and for rooting $0.5 \mathrm{gm} / \mathrm{L}$ NAA is recommended. After 15 days of culture of microshoots on rooting medium, the plantlets were transplanted to plastic pots for acclimatization. 

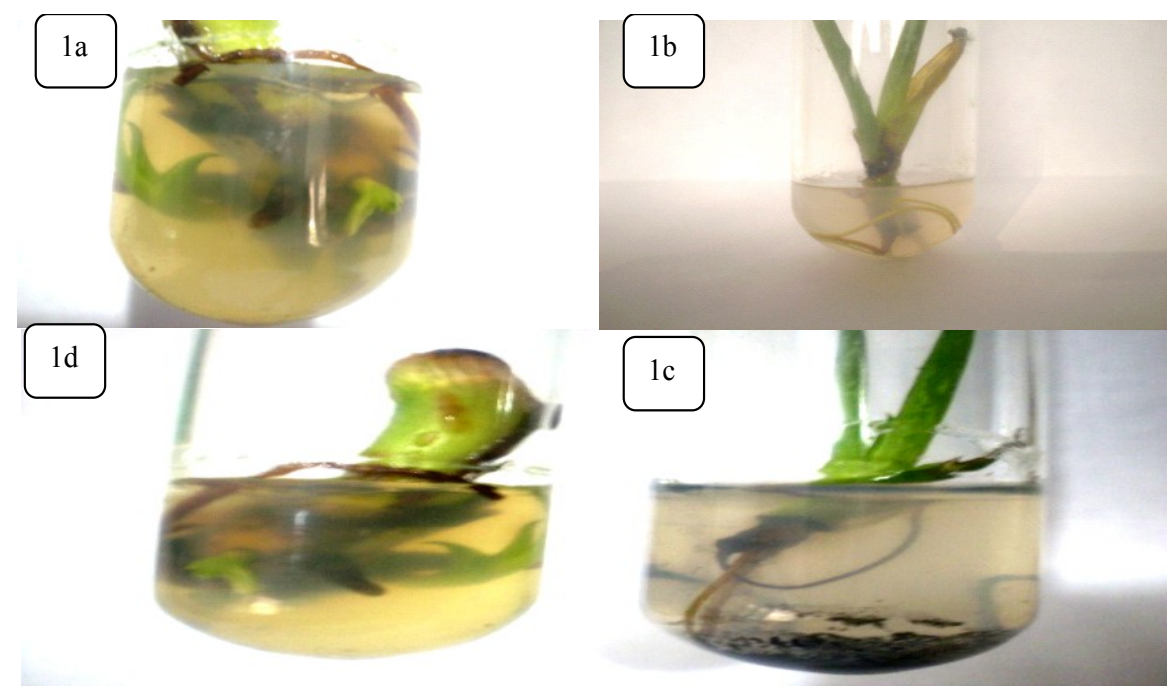

Fig. 3.1 Highest shoot formation (1a), highest root formation (1b), without activated charcoal (1c) and, brown color and with activated charcoal (1d).

\section{Discussion}

A number of factors such as genotype, culture medium (including growth regulators and their combinations), physical environment, explants develop-mental stage, etc affect adventitious shoot regeneration from tissue cultured explants [16]. Therefore, present study attempted to optimize the growth regulator and their concentration for efficient direct shoot regeneration from lateral shoot explants of Aloe indica while controlling the phenolic browning. Moreover, the in vitro regeneration of direct adventitious shoots is an essential component to produce plants from elite materials as to avoid formation of somaclones.

In the present study, shoot proliferation occurred only in the presence of cytokinin. But the results of current research also showed the best ratio of BA to NAA for buds initiation, shoot proliferation was 1:1 or 2:1. Among the cytokinins tested, Kn proved to me more effective. The finding of this research work is close to work off [17] and [18]. The current work is in contrast to earlier reports in Aloe Vera by [9] and [19] in Aloe vera. These researchers reported that better proliferation occurred on medium containing Kn instead of BA in Aloe vera. This difference may be due to difference in the genotype of plant used. [20] and [21] reported use of BA in shoot proliferation of Aloe polyphylla and A.vera respectively. In order to reflect the differences among the factors and to identify the optimum medium, ANOVA (analysis of variance) was carried out. Factors, namely BA, NAA and reciprocal effect of BA and NAA, had significantly different effects on proliferation of $A$. indica $(\mathrm{p}<0.05)$. The statistical funding concludes that BA with NAA had more effect than only BA or Kn, which is also supported by [18].

From this study, rooting percentage was improved in the presence of low concentrations of IBA and NAA. Our findings support those of [22]. In the previous studies, [23] reported rooting (100\%) in A. vera and rose in hormone-free medium. Our results do not support these observations. In order to reflect the differences among the factors and to identify the optimum medium, ANOVA (analysis of variance) was carried out. Factors, namely NAA, IBA and IAA had significantly different effects on proliferation of $A$. vera $(\mathrm{p}<0.05$.). The statistical funding concludes that NAA had more effect than IBA, which is also supported by [18].

\section{Conclusion}

Micropropagation is the process which used to save the endangered plant species as well as cost of various plantlet productions. In this thesis work, we found the encouraging result of hormone effects for commercial micropropagation of Aloe indica L. For future research more doses of hormone combination can be taken as treatments with fewer intervals which will give us specific result. At the same time except BA, Kn, NAA and IBA other types of cytokinin and auxine can be taken into consideration. Except shoot tip culture, meristem and callus culture could be practiced. The present study described an efficient protocol for shoot proliferation of Aloe vera with $90 \%$ development of shoots per explants with better quality plantlets in terms of growth. Higher shoot number reported in the present study in the shoot induction media could be attributed to the beneficial effect of activated charcoal in culture media. Rooting is more flexible in rooting medium. Moreover, $100 \%$ survival of plants after acclimatization could be achieved. Hence, the shoot regeneration procedure described in the present study could be ideal for rapid micropropagation of elite plants of Aloe indica L. By this protocol in future we could be decreased the cost of Aloe indica production which will lead the decrease of aloe product prices. 


\section{Acknowledgements}

We are grateful to the Bangladesh Council of Scientific and Industrial Research (BCSIR) Laboratories, Rajshahi, Bangladesh and also to the department of Genetic Engineering and Biotechnology, Shahjalal University of Science and Technology, Sylhet-3114, Bangladesh.

\section{References}

[1] I.E. Dandhof, "Remarkable Aloe", Omnimedicus Press, Grand Prairie, 1987,Texas, 100-112.

[2] P. Atherton, "Aloe vera: Magic or Medicine", Nurs. Stand. 12, 41-52, 1998.

[3] Jeffrey Bland, Effect of Orally Consumed Aloe Juice on Gastrointestinal Function in Normal Humans, Linus Pauling Institute of Science and Medicine, Palo Alto, Cal., Preventive Medicine, 22, 256-280, 1985.

[4] F. Borrelli, A.A. Izzo, The Plant Kingdom as a Source of Anti Ulcer Remedies, Phytother. Res., 14, 581-591, 2000

[5] J.E. Crew, Aloes in the Treatment of Burns and Scalds, Minnesota Med, 22, 538-539.1939.

[6] L.M. Cera, J.P. Heggers, M.C. Robson and W.J. Hagstrom, The Therapeutical Efficacy of Aloe vera Cream (Dermaid Aloe) in Thermal Injuries: Two Case Reports, Journal of the American Animal Hospital Association, 16, 786-772,1988.

[7] R.H. Davis, Isolation of a Stimulatory System in an Aloe vera Extract, J. Amer. Podiatric Med. Assoc., 81(9), 234-256, 1991.

[8] W.D. Lane, In vitro propagation of Spirea bumalda and Prunus cistena from shoot apics, Can., J. Plant Sci., 59, 1025-1029,1979.

[9] H.J. Meyer, and J.V. Staden, Rapid in vitro propagation of Aloe barbadensis Mill., Plant cell, Tissue and Organ Culture, 26,167$171,1991$.

[10] P. Bridge, The production of strawberry plants by in vitro micropropagation, J.Hortic. Sci., 49, 209-211, 1974.

[11] R.K.L. Drew, Effect of activated charcoal on embryo genesis and regeneration of plantlets from suspension culture of carrot (Daucus carota .), Ann. Bot., 44, 387-389, 1979.

[12] W Roca, L Mroginski, Establecimiento de cultivos de tejidos vegetales in vitro. In: Cultivo de tejidos en la agricultura. Fundamentos y Aplicaciones. Cali, Centro Internacional de Agricultura Tropical. 34, 19-41, 1991.

[13] R.K.L Drew, Effect of activated charcoal on embryo genesis and regeneration of plantlets from suspension culture of carrot (Daucus carota.), Ann. Bot. 44, 387-389, 1997.

[14] T Murashige and F Skoog, A revised medium for rapid growth and bioassay with tobacco tissue cultures, Physiol. Plant., 15, 473497,1962

[15] S.C. Roy and A Sarkar, In vitro regeneration and micropropagation of Aloe vera L., Sci Hortic-Amsterdam, 47, 107-113, 1991.

[17] S. Ahmed, A.H. Kabir, M.B. Ahmed, M.A. Razvy And S. Ganesan, Development of rapid micropropagation method of Aloe vera L., Sjemenastvo 24, 324-333, 2007.

[18] D. Hashemabadi and Behzad Kaviani, Rapid micro-propagation of Aloe vera L. via shoot multiplication, African Journal of Biotechnology 7 (12), 1899-1902, 2008.

[19] I Natali, IC Sanchez, A Cavallini, In vitro culture of Aloe barbadensis Mill. Micropropagation from vegetative meristem, Plant Cell, Tiss. Org. Cult., 20, 41-47, 1990.

[20] AI Abrie and JV Staden, Micropropagation of the endangered Aloe polyphylla, Plant Growth Regul., 33, 19-23, 2001.

[21] S. Chaudhuri, and U. Mukundan, Aloe Vera L.-Micropropagation and Characterization of its gel, Phytomorphology, 51(2), 155157,2001

[22] Z Liao, M Chen, F Tan, X Sun, K Tang, Micropropagation of endangered chinese aloe, Plant cell, Tiss. Org. Cult., 76, 83-86, 2004

[23] D Aggarwal and KS Barna, Tissue culture propagation of elite plant of Aloe vera L., J Plant Biochem Biotech., 13, 77- 79, 2004. 